\title{
PENGARUH RASIO LEVERAGE DAN PROFITABILITAS TERHADAP NILAI PERUSAHAAN INDUSTRI MAKANAN DAN MINUMAN YANG TERDAFTAR DI BURSA EFEK INDONESIA
}

\author{
Alfret Kristanto Dewanto \\ Muslimin \\ Yunus Kasim \\ Jurusan Manajemen, Fakultas Ekonomi, Universitas Tadulako \\ Email : alfreddewanto@gmail.com
}

\begin{abstract}
Sample in study consists of 11 companies that were selected by purposive sampling method. Data collecting technique is documentary analysis using the data of annual reports of food and beverage companies listed on Indonesia Stock Exchange in 2010 - 2014. Method of data analysis uses panel data and multiple linear regressions with software Eviews version 7. The results show that six independent variables studied simultaneously influence the company value with sig. probability 0.000011 and F-count $<0.05$. The t-tests indicate that the Times Interest Earned Ratio, Long termDebt to Equity Ratio, ROA, NPM and ROE have no significant influence on the company value: X2 = $0.2845, X 3=0.1626, X 4=0.0576,0.2678=X 5, X 6=0.6344,0.05 \geq \alpha$. Debt Ratio has significant influence on company value, with the value $X 1=0.0192 \leq 0.05 . R^{2}$ value is 0.483863 and simultaneously, six independent variables studied influence the dependent variable (the value of the company) of $48.38 \%$, while the remaining $51.62 \%$ influenced by other variables that are not studied.
\end{abstract}

Keywords: leverage, profitability, company value

\section{ABSTRAK}

Sampel dalam penelitian ini sebanyak 11 perusahaan diambil berdasarkan metode purposive sampling. Pengumpulan data dilakukan dengan metode dokumentasi dalam penelitian ini menggunakan data yang tersedia dalam laporan tahunan perusahaan makanan dan minuman tahun 2010 - 2014 melalui situs yang dimiliki oleh Bursa Efek Indonesia, yakni www.idx.co.id. Metode analisis data dilakukan dengan metode regresi data panel menggunakan bantuan software EVIEWS versi 7. Hasil penelitian menunjukkan bahwa keenam variable independen yang diteliti terbukti secara serempak berpengaruh terhadap variabel dependen Nilai Perusahaan dengan nilai sig probabilitas $F$ hitung 0,000011 < 0,05. Kemudian melalui uji t dapat diketahui bahwa Times Interest Earned Ratio, Long ter-debt to Equity Ratio, ROA, NPM dan ROE tidak berpengaruh signifikan terhadap nilai perusahaan, dengan nilai masing-masing $X 2=0,2845, X 3=0,1626, X 4=0,0576, X 5=0,2678, X 6=$ $0,6344, \geq \alpha$ 0,05. Sedangkan Debt Ratio berpengaruh signifikan terhadap Nilai Perusahaan, dengan nilai X1 =0,0192 $\leq 0,05$. Nilai $R 2$ sebesar 0,483863 dengan demikian keenam variabel bebas yang diteliti secara serempak memberikan pengaruh terhadap variabel terikat (Nilai Perusahaan) sebesar 48,38\% sementara sisanya 51,62\% dipengaruhi oleh variabel lain yang tidak diteliti.

Kata Kunci: Leverage, Profitabilitas, dan Nilai Perusahaan

\section{PENDAHULUAN}

Manajemen keuangan dalam bisnis modern dikaitkan dengan keputusan investasi, pembiayaan, deviden dan pengelolaan aset. Keputusan investasi menyangkut alokasi dana, baik yang berasal dari dalam perusahaan maupun dari luar perusahaan. Keputusan pembiayaan berkaitan dengan keputusan perusahaan dalam pemilihan pembiayaan investasi atau aktivanya, atau apakah perusahaan lebih mengutamakan hutang atau modal sendiri. Tujuan perusahaan pada umumnya adalah untuk meningkatkan nilai perusahaan. Sebagaimana dinyatakan Brigham-Gapenksi (1996), tujuan perusahaan dikaitkan dengan dengan meningkatkan nilai, melalui peningkatan kemakmuran atau para pemegang saham. Peningkatan kemakmuran pemilik atau para pemegang saham tersebut dapat dinyatakan dengan membaiknya harga saham perusahaan. 
Nilai perusahaan dapat dilihat dari Price to Book Value (PBV) yang merupakan perbandingan antara harga saham dengan nilai buku per lembar saham (Ang, 1997).

Hal ini ditandai dengan jumlah transaksi perusahaan yang go public, investor, dan pelaku pasar modal lainnya yang terus meningkat (Stevanie:2010). Menurut Bastian dan Suhardjono (2006: 299) Net Profit Margin adalah perbandingan antara laba bersih dengan penjualan. Semakin besar NPM, maka kinerja perusahaan akan semakin produktif, sehingga akan meningkatkan kepercayaan investor untuk menanamkan modalnya pada perusahaan tersebut.

Penelitian dilakukan menganalisis fenomena ini, atau secara lebih eksplisit akan menjawab pertanyaan apakah kebijakan hutang dan profitabilitas mempengaruhi nilai perusahaan. Penelitian ini difokuskan pada industri makanan dan minuman yang terdaftar di Bursa Efek Indonesia (BEI).

Berdasarkan permasalahan yang diajukan, maka penelitian ini bertujuan :

1. Untuk mengetahui apakah Debt ratio, times interest earned ratio, long-term debt to equity ratio, ROA, ROE dan NPM secara bersama-sama berpengaruh signifikan terhadap nilai perusahaan industri makanan dan minuman yang terdaftar di BEI.

2. Untuk mengetahui apakah Debt Ratio secara parsial berpengaruh signifikan terhadap nilai perusahaan industri makanan dan minuman yang terdaftar di BEI.

3. Untuk mengetahui apakah Times Interest Earned Ratio secara parsial berpengaruh signifikan terhadap nilai perusahaan industri makanan dan minuman yang terdaftar di BEI.

4. Untuk mengetahui apakah Long-Term Debt to Equity Ratio secara parsial berpengaruh signifikan terhadap nilai perusahaan industri makanan dan minuman yang terdaftar di BEI.

5. Untuk mengetahui apakah ROA secara parsial berpengaruh signifikan terhadap nilai perusahaan industri makanan dan minuman yang terdaftar di BEI.

6. Untuk mengetahui apakahNPM secara parsial berpengaruh signifikan terhadap nilai perusahaan industri makanan dan minuman yang terdaftar di BEI.

7. Untuk mengetahui apakah ROE secara parsial berpengaruh signifikan terhadap nilai perusahaan industri makanan dan minuman yang terdaftar di BEI.

\section{KAJIAN LITERATUR DAN PENGEMBANGAN HIPOTESIS}

\section{Rasio Leverage}

Leverage (Hutang) merupakan kewajiban perusahaan kepada pihak lain untuk membayar sejumlah uang atau menyerahkan barang atau jasa pada tanggal tertentu.

\section{Rasion Profitabilitas}

Menurut Saidi (2004), profitabilitas adalah kemampuan perusahaan dalam memperoleh laba. Para investor menanamkan saham pada perusahaan adalah untuk mendapatkan return. Semakin tinggi kemampuan perusahaan memperoleh laba, maka semakin besar return yang diharapkan investor, sehingga menjadikan nilai perusahaan menjadi lebih baik.

\section{Nilai Perusahaan (FV)}

Nilai perusahaan merupakan persepsi investor terhadap perusahaan, yang sering dikaitkan harga saham. Harga saham yang tinggi membuat nilai perusahaan juga tinggi. Harga saham merupakan harga yang terjadi pada saat saham diperdagangkan di pasar

\section{METODE PENELITIAN}

Objek penelitian ini adalah industri makanan dan minuman yang terdaftar di Bursa Efek Indonesia (BEI) periode 2010-2014. Dalam penelitian ini, peneliti menggunakan 1 variabel dependen dan 6 variabel independen. Menurut Sugiyono (2009) variabel independen atau dalam bahasa Indonesia sering disebut variabel terikat adalah variabel yang dipengaruhi atau yang menjadi akibat, karena adanya variabel bebas. Menurut Sugiyono (2009) Variabel dependen atau dalam bahasa Indonesia di 
sebut variabel bebas adalah variabel yang mempengaruhi atau yang menjadi sebab perubahannya atau timbulnya variabel dependen (terikat), yang menjadi variabel dependen dalam penelitian ini adalah nilai perusahaan.

\section{Rasio Leverage}

1. Debt Ratio( Rasio Hutang)

2. Times Interest Earned Ratio (TIE)

3. Long-Term Debt To Equity Ratio (LTD)

\section{Rasio Profitabilitas}

1. Return On Asset (ROA)

2. Net Profit Margin (NPM)

3. Return on Equity (ROE)

Selanjutnya populasi dalam penelitian ini yaitu perusahaan yang tergabung dalam kelompok perusahaan manufaktur sektor industri makanan dan minuman yang terdaftar di Bursa Efek Indonesia (BEI) pada tahun 2010-2014. Total perusahaan yang terdaftar dalam kelompok perusahaan manufaktur sektor industri makanan dan minuman berjumlah 15 perusahaan. Total 15 perusahaan tersebut kemudian dipilih berdasarkan kriteria yang di butuhkan dalam penelitian agar dapat dijadikan sampel dalam penelitian. Data industri makanan dan minuman yang terdaftar di BEI diketahui bahwa jumlah perusahaan yangterdaftar pada periode 2010-2014 sebanyak 16 perusahaan, berdasarkan kriteria diatas maka sampel yang digunakan dalam penelitian ini sebanyak 11 perusahaan.

Metode analisa yang digunakan adalah analisis regresi data panel, dan pengujian hipotesis $\mathrm{F}$ dan uji hpotesis t. Kemudian Analisis Data Panel. Data panel sendiri merupakan gabungan antara data runtut waktu (time series) dan data silang (cross section). Mengingat data panel merupakan gabungan dari data time series dan cross section, maka untuk menguji hipotesis-hipotesis yang telah dirumuskan dalam penelitian ini, modelnya dapat dituliskan sebagai berikut:

Keterangan:

$$
\text { Yit }=\alpha+\beta 1 X 1 \text { it }+\beta 2 X_{2} \text { it }+\beta 3 \text { X3it }+\beta 4 \text { X4it }+\varepsilon
$$

$\mathrm{Y}=$ Discretionary accruals (Proyeksi Nilai perusahaan); $\alpha=$ Konstanta; $\beta=$ Koefisien Regresi masing-masing variabel independen; $\mathrm{X}_{1}=$ Debt Ratio; $\mathrm{X}_{2}=$ Times interest of ratio; $\mathrm{X}_{3}=$ Long term debt to equity ratio; $\mathrm{X}_{4}=\mathrm{ROA} ; \mathrm{X}_{5}=\mathrm{ROE} ; \mathrm{X}_{6}=\mathrm{NPM} ; \varepsilon=$ Errorterm $; \mathrm{t}=$ Waktu; $\mathrm{i}=$ Perusahaan

\section{Metode Pemilihan Data}

Pertama yang harus dilakukan adalah melakukan uji $\mathrm{F}$ untuk memilih metode mana yang terbaik diantara ketiga metode tersebut dilakukan uji Chow dan uji Hausmant. Uji Chow dilakukan untuk menguji antara metode commont effect dan fixed effect. sedangkan uji Hausmant dilakukan untuk menguji apakah data dianalisis dengan menggunakan fixed effect atau random effect, pengujian tersebut dilakukan dengan Eviews 6.

\section{Pengujian Hipotesis}

Uji $\mathrm{F}$ digunakan untuk mengetahui ada tidaknya pengaruh secara bersama-sama antara variabel bebas terhadap variabel terikat. Tingkat signifikansi yang digunakan adalah sebesar 5\%, dengan derajat kebebasan df $=(n-k-1)$, dimana $(n)$ adalah jumlah observasi dan $(\mathrm{k})$ adalah jumlah variabel.

\section{Koefisien Determinasi $\left(\mathbf{R}^{2}\right)$}

Koefisien determinasi $\left(\mathrm{R}^{2}\right)$ pada intinya mengukur seberapa jauh kemampuan model dalam menerangkan variasi variabel dependen (Ghozali, 2011). 


\section{Pengujian Signifikan Simultan (uji F statistic)}

Uji F digunakan untuk mengetahui secara bersama-sama apakah variabel bebas berpengaruh secara signifian atau tidak terhadap variabel terikat (Ghozali, 2011).

\section{Pengujian Parsial (uji t statistic)}

Uji keberartian koefisien (bi) dilakukan dengan statistik-t. Hal ini digunakan untuk menguji koefisien regresi secara parsial dari variabel independennya

\section{HASIL DAN PEMBAHASAN}

\section{Uji Statistik Deskriptif}

Pada bagian ini akan digambarkan atau dideskripsikan data informasi mengenai variabel-variabel penelitian seperti nilai perusahaan (FV), Debt Ratio, Time Interest Earned Ratio (TIE), Long termdebt to Equity Ratio (LTD), ROA, NPM, dan ROE pada tahun 2010 sampai dengan 2014 yang dilihat dari nilai minimum, nilai maksimum, nilai rata - rata (mean) dan standar deviasi dari masing-masing variabel yang disajikan dalam Tabel 1 .

Tabel 1 Hasil Uji Statistik Deskriptif

\begin{tabular}{|c|c|c|c|c|c|c|c|}
\hline & Debt & TIE & $\angle T D$ & ROA & NPM & ROE & FV \\
\hline Mean & 0,4505 & 20,1560 & 1013,4929 & 0,1343 & 0,0995 & 0,2684 & 1,7582 \\
\hline Standard Error & 0,0197 & 3,9229 & 390,9096 & 0,0165 & 0,0095 & 0,0416 & 0,2419 \\
\hline Median & 0,4743 & 8,0666 & 72,7077 & 0,0913 & 0,0881 & 0.1904 & 1,2871 \\
\hline $\begin{array}{l}\text { Standard } \\
\text { Deviation }\end{array}$ & 0,1463 & 29,0932 & 2899,0629 & 0.1224 & 0,0703 & 0,3087 & 1,7938 \\
\hline Sample Variance & 0,0214 & 846,4118 & 8404565,4832 & 0,0150 & 0,0049 & 0,0953 & 3,2176 \\
\hline Kurtosis & $-0,6773$ & 15,2146 & 9,3943 & 5,6540 & 2,4731 & 7,1002 & 17,6785 \\
\hline Skewness & $-0,2199$ & 3,4489 & 3,2322 & 2,2020 & 1,5309 & 2,7621 & 3,5758 \\
\hline Range & 0,5892 & 174,2446 & 13112,3913 & 0,6330 & 0,3183 & 1,3945 & 11,4722 \\
\hline Minimum & 0,1626 & 2,0073 & 0,0000 & 0,0242 & 0,0105 & 0,0409 & 0,3086 \\
\hline Maximum & 0,7518 & 176,2519 & 13112,3913 & 0,6572 & 0,3288 & 1,4353 & 11,7807 \\
\hline Sum & 24,7774 & 1108,5807 & 55742,1097 & 7,3892 & 5,4726 & 14,7613 & 96,6994 \\
\hline Count & 55 & 55 & 55 & 55 & 55 & 55 & 55 \\
\hline
\end{tabular}

Berdasarkan hasil uji statistik deskriptif pada tabel di atas, diperoleh informasi bahwa dari ketujuh variabel penelitian yang diteliti terdapat tiga variabel yang memiliki data yang baik (Debt, ROA, NPM), dimana ketiga variabel tersebut memiliki nilai mean yang lebih tinggi dibandingkan dengan standar deviasinya, sedangkan empat variabel lainnya yang diteliti memiliki nilai mean berada dibawah nilai standar deviasinya, hal ini menjelaskan bahwa ke empat variabel tersebut memiiki data yang kurang baik.

Standar deviasi $(\sigma)$ menunjukkan seberapa jauh kemungkinan nilai yang diperoleh menyimpang dari nilai yang diharapkan.Semakin besar nilai standar deviasi maka semakin besar kemungkinan nilai riil menyimpang dari yang diharapkan. Dalam kasus seperti ini, dimana nilai mean masing-masing variabel lebih kecil dari pada standar deviasinya, biasanya di dalam data terdapat outlier (data yang terlalu ekstrim). Outlier adalah data yang memiliki karakteristik unik yang terlihat sangat berbeda jauh dari observasi-observasi lainnya dan muncul dalam bentuk nilai ekstrim. Data-data outlier tersebut biasanya akan mengakibatkan tidak normalnya distribusi data.

\section{Deskripsi Hasil Penelitian \\ Debt Ratio( $\left.\mathbf{X}_{\mathbf{1}}\right)$}

Berdasarkan laporan keuangan perusahaan Makanan dan Minuman di Bursa Efek Indonesia diperoleh data Debt Ratio selama periode 2010-2014, yang disajikan dalam bentuk Gambar 1: 


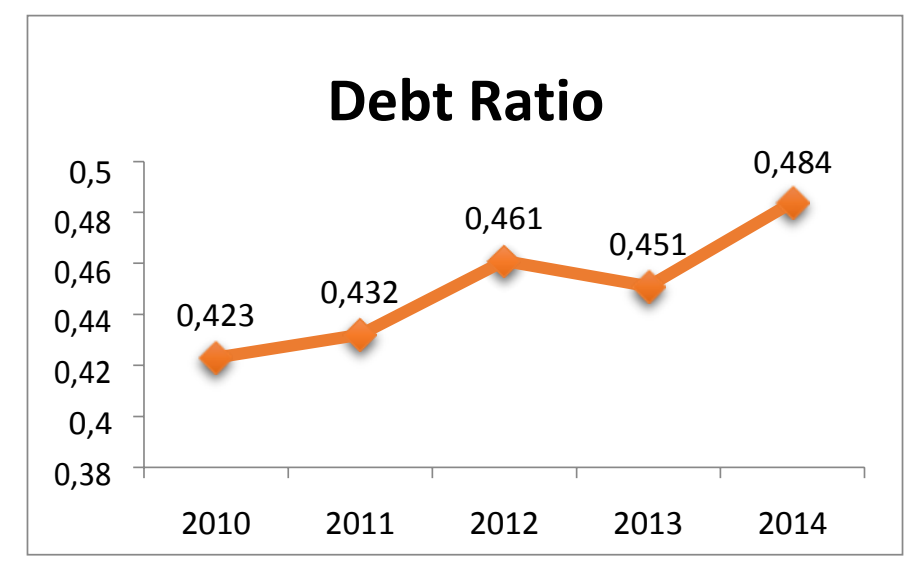

Gambar 1

Perkembangan Debt Ratio (Rasio Hutang) Industri Makanan dan Minuman di Bursa Efek Indonesia Periode 2010-2014

Gambar 1 memperlihatkan perkembangan rata - rata debt ratio industri makanan dan minuman selama lima tahun yang berfluktuasi, seperti yang terlihat debt ratio mengalami penurunan dan peningkatan sebanyak 2 kali. Penurunan secara signifikan terjadi pada tahun 2013 sebesar 0,01. Hal ini mengindikasikan bahwa pada tahun tersebut total hutang industri ini mengalami penurunan yang diikuti dengan meningkatnya total aset mereka, namun penurunan tersebut masih kecil bila dibandingkan dengan peningkatan debt ratio pada tahun 2012 dan tahun 2014 sebesar 0,04 dan 0,033 hal ini ini dikarenakan perusahaan - perusahaan meningkatkan jumlah aset mereka dengan meningkatkan total hutang sebagai salah satu alternatif pendanaan.

\section{Times Interest Earned Ratio $\left(\mathbf{X}_{2}\right)$}

Beban bunga merupakan salah satu biaya tetap yang wajib dibayar oleh masing masing perusahaan. Rasio ini mengukur kemampuan perusahaan membayar biaya tersebut dengan menggunakan EBIT (Earning Before Interest and Taxes).

Berikut perkembangan Times Interest Earned Ratio perusahaan industri Makanan dan Minuman yang go public di Bursa Efek Indonesia, dapat dilihat pada Gambar:

\section{Times Interest Earned Ratio}

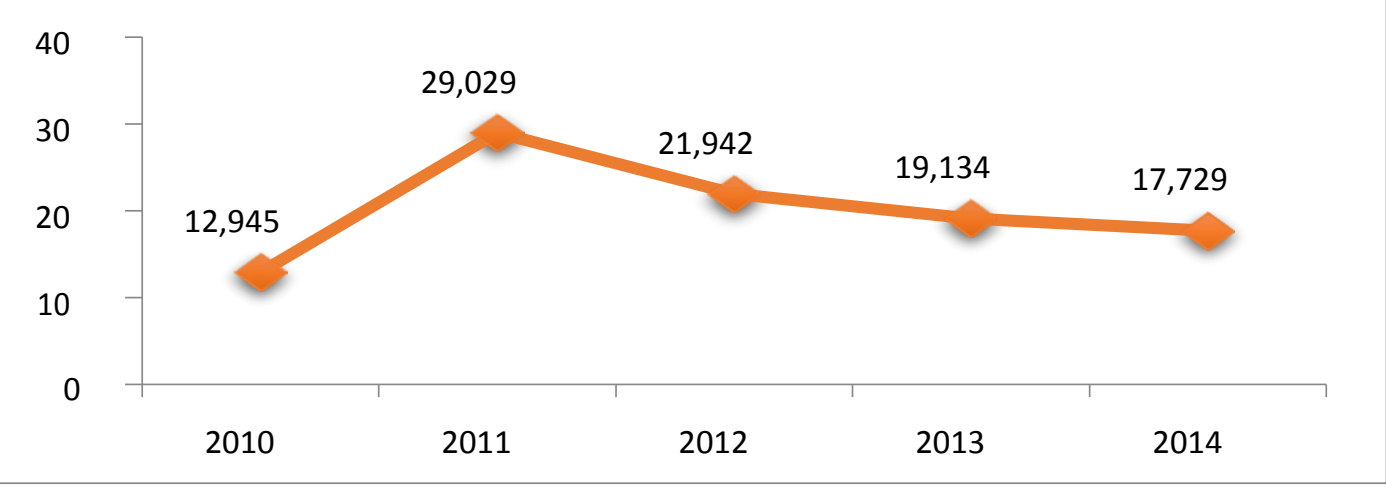

\section{Gambar 2}

Perkembangan Times Interest Earned ratio Industri Makanan dan Minuman di Bursa Efek Indonesia periode 2010-2014 
Berdasarkan Gambar 2 dapat kita perhatikan bahwa perkembangan times interest earned ratio pada tahun 2011 mengalami peningkatan yang signifikan sebesar 17,048 hal ini dikarenakan total EBIT industri makanan dan minuman yang di peroleh pada tahun tersebut jauh lebih tinggi jika dibandingkan dengan total beban bunganya. Perkembangan times interest earned ratio dari tahun 2011 - 2014 terus mengalami penurunan, hal ini dikarenakan peningkatan EBIT perusahaan - perusahaan dalam industri ini selama 4 tahun di ikuti dengan meningkatnya beban bunga yang cukup besar, namun apabila kita perhatikan nilai penurunannya masih dalam keadaan normal yang mengindikasikan bahwa perusahaan - perusahaan dalam industri ini tetap mampu memenuhi kewajibannya untuk membayar biaya tetap berupa bunga.

\section{Long term-debt to Equity Ratio $\left(\mathbf{X}_{3}\right)$}

Pada Gambar 4.3 kita dapat mengamati perkembangan long term-debt to equity ratio dari tahun 2010 - 2012 terus mengalami peningkatan hal ini mengindikasikan bahwa hutang jangka panjang lebih banyak membiayai keuangan perusahaan dibandingkan dengan modal sendiri yang dimiliki tiap - tiap perusahaan. Hal ini mengartikan bahwa peningkatan hutang jangka panjang tidak diikuti dengan bertambahnya modal pribadi yang dimiliki, sehingga meningkatkan resiko leverage keuangan perusahaan. Pada tahun 2013 - 2014 rasio ini mengalami penurunan, dimana penurunan secara signifikan terjadi pada tahun 2013 sebesar 357,135, kondisi ini disebabkan oleh adanya pengurangan tingkat hutang jangka panjang perusahaan, sehingga resiko leverage keuangan perusahaan perusahaan industri makanan dan minuman juga mengalami penurunan.

Adapun perkembangan Long term-debt to Equity Ratio perusahaan Industri Makanan dan Minuman di Bursa Efek Indonesia periode 2010 - 2014 sebagai berikut:

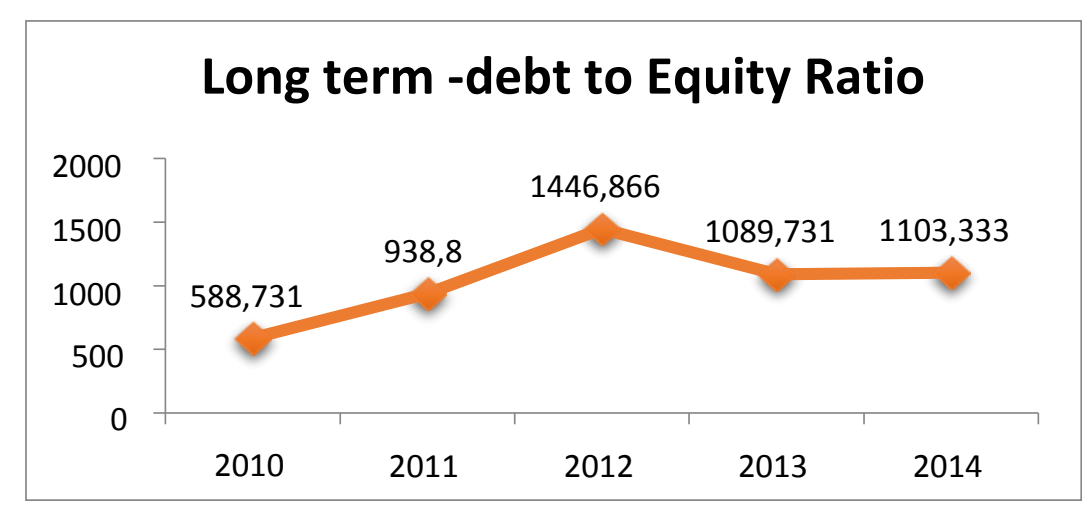

Gambar 3

Perkembangan Long term debt to Equity Ratio Industri Makanan dan Minuman di Bursa Efek Indonesia Periode 2010-2014

\section{$\operatorname{ROA}\left(\mathbf{X}_{4}\right)$}

Perkembangan ROA perusahaan Industri Makanan dan Minuman di Bursa Efek Indonesia periode 2010 - 2014 sebagai berikut: 


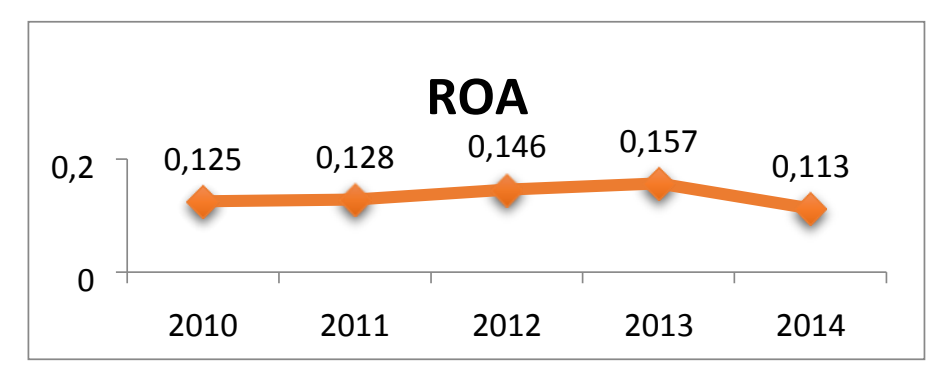

Gambar 4

Perkembangan ROA Industri Makanan dan Minuman di Bursa Efek Indonesia Periode 2010-2014

Berdasarkan Gambar 4kita dapat menyimpulkan bahwa perkembangan ROA industri makanan dan minuman dapat dikatakan terus membaik dengan peningkatan yang diperoleh selama 4 tahun yaitu tahun 2010 - 2013. Hal ini mengindikasikan bahwa kemampuan perusahaan - perusahaan yang termasuk didalam industri makanan dan minuman dalam mengelola seluruh aktivanya untuk menghasilkan laba terus membaik setiap tahunnya. Berbeda pada tahun 2014 dimana ROA industri makanan dan minuman mengalami penurunan cukup signifikan sebesar 0,044 , dimana rata-rata laba setelah pajak yang dihasilkan oleh industri ini juga mengalami penurunan.

\section{$\operatorname{NPM}\left(\mathbf{X}_{5}\right)$}

Perkembangan NPM perusahaan Industri Makanan dan Minuman di Bursa Efek Indonesia periode 2010 - 2014 sebagai berikut:

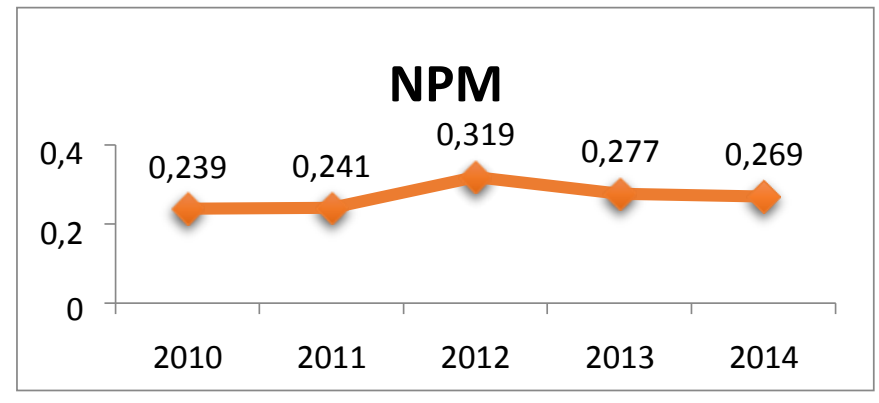

Gambar 5

Perkembangan NPM Industri Makanan dan Minuman di Bursa Efek Indonesia Periode 2010-2014

Berdasarkan Gambar 5 kita dapat mengamati perkembangan NPM industri makanan dan minuman selama lima tahun mengalami perkembangan yang berfluktuasi, meski demikian perkembangan tersebut tidak memperlihatkan perubahan yang drastis, hanya saja pada tahun 2012 yang mengalami peningkatan yang paling tinggi selama kurun waktu lima tahun sebesar 0,078 dan mengalami penurunan yang paling tinggi tahun 2013 sebesar 0,042.I

\section{ROE $\left(\mathbf{X}_{6}\right)$}

Perkembangan NPM perusahaan Industri Makanan dan Minuman di Bursa Efek Indonesia periode 2010 - 2014 sebagai berikut: 
Dewanto A.K.

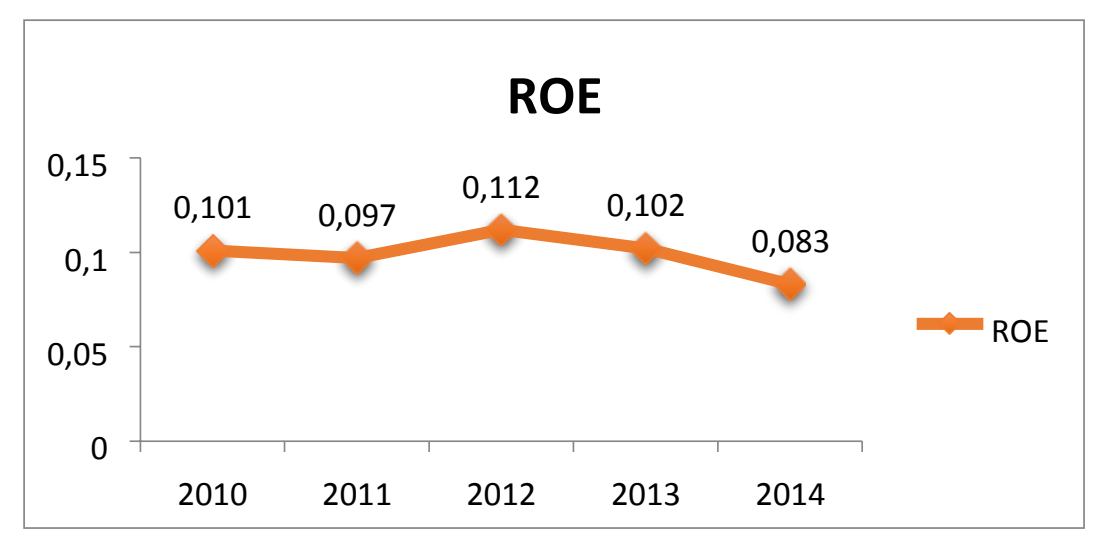

Gambar 6

Perkembangan ROE Industri Makanan dan Minuman di Bursa Efek Indonesia Periode 2010-2014

Berdasarkan Gambar 6 dapat kita perhatikan bahwa ROE industri makanan dan minuman terus mengalamami penurunan selama 3 tahun yaitu tahun 2011, 2013 dan 2014 masing - masing sebesar 0,04, 0,01 dan 0,019. Namun perkembangan ROE mengalami peningkatan yang sedikit signifikan pada tahun 2012 sebesar 0,015. Hal ini memberikan arti bahwa selama kurun waktu lima tahun kontribusi modal sendiri dalam menghasilkan laba setelah pajak paling tinggi adalah tahun 2012, dengan kata lain selama 4 tahun terakhir pengelolaaan modal sendiri untuk menghasilkan laba mengalami penurunan.

\section{Nilai Perusahaan (Y)}

Perkembangan Nilai Perusahaan perusahaan Industri Makanan dan Minuman di Bursa Efek Indonesia periode 2010 - 2014 sebagai berikut:

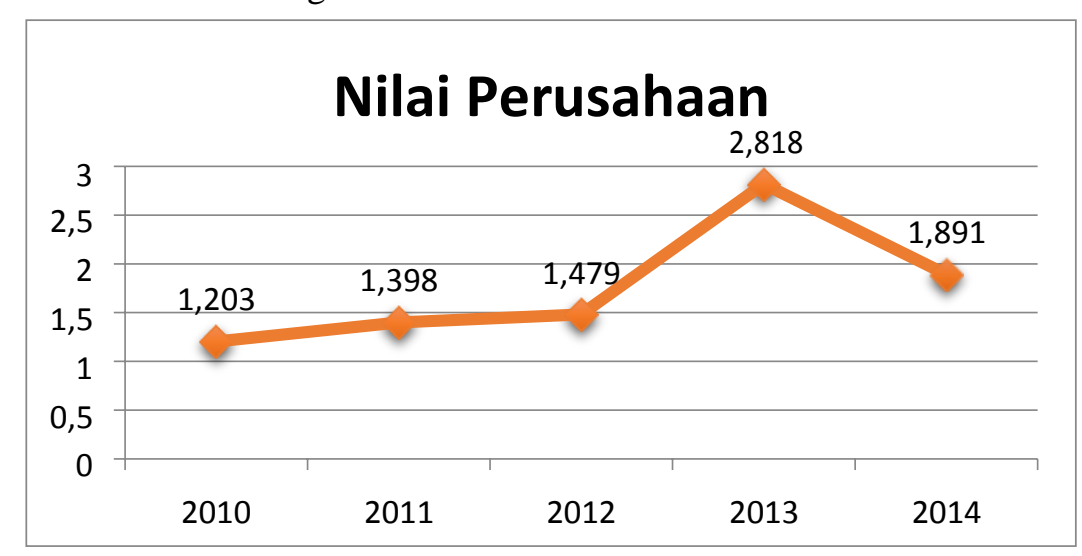

Gambar 7

Perkembangan Nilai Perusahaan Industri Makanan dan Minuman di Bursa Efek Indonesia Periode 2010-2014

Berdasarkan Gambar 7 nilai perusahaan industri makanan dan minuman terus mengalami peningkatan selama 4 tahun yakni tahun 2010 - 2013. Peningkatan paling tinggi terjadi pada tahun 2013 dengan nilai2.818. Dari gambar diatas, kita pula dapat melihat terjadi penurunan yang cukup signifikan pada tahun 2014 dengan nilai1,891 namun penurunan ini masih kecil dibandingkan dengan peningkatannya. Dengan demikian mengindikasikan bahwa nilai perusahaan industri makanan dan minuman selama kurun waktu lima tahun dapat dikatakan baik, karena apabila kita perhatikan nilai perusahaan industry ini setiap tahunnya bernilai diatas satu "Jika Tobin's Q diatas satu, ini menunjukkan bahwa investasi dalam aktiva menghasilkan laba yang memberikan nilai yang lebih 
tinggi daripada pengeluaran investasi, hal ini akan merangsang investasi baru. Jika Tobin's Q di bawah satu, investasi dalam aktiva tidaklah menarik. Jadi Tobin's Q merupakan ukuran yang lebih teliti tentang seberapa efektif manajemen memanfaatkan sumber-sumber daya ekonomis dalam kekuasaannya" (viola Herawati 2008:7).

\section{Pemilihan Model Regresi Data Panel}

Pemilihan model tersebut melalui beberapa pengujian. Pengujian yang dimaksud adalah uji chow yang digunakan untuk memilih Common Effect Method atau Fixed Effect Method dan Uji hausman digunakan untuk memilih Fixed Effect Method atau Random Effect. Berikut merupakan hasil uji chow dan uji hausman:

Tabel 2 Hasil Uji Model Menggunakan Chow Test

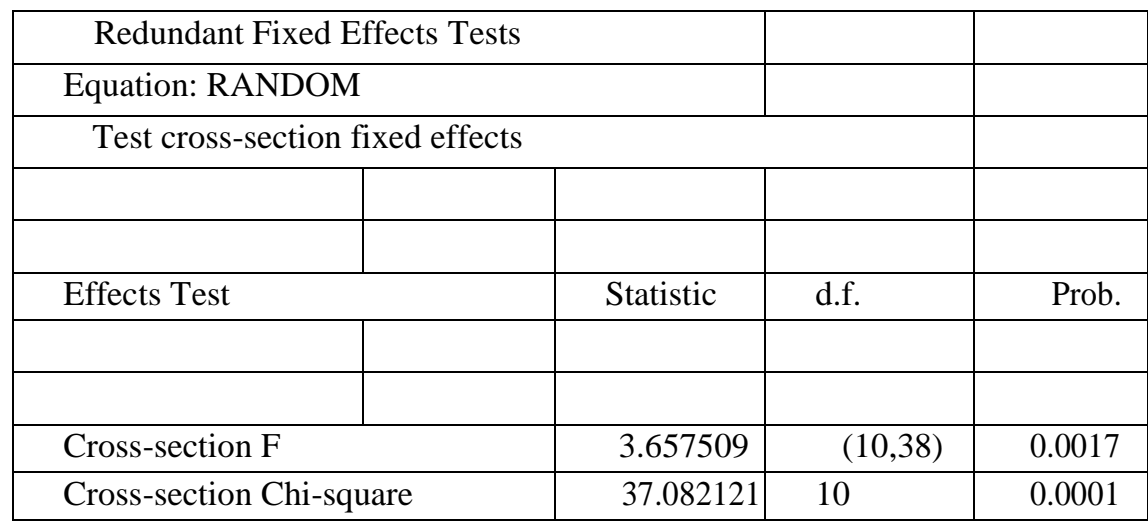

Berdasarkan hasil uji chow mengenai pemilihan modei antara common effect dan fixed effect diperoleh hasil probability Fsebesar 0,0017<0,05. Sehingga keputusan yang diambil pada chow test ini yaitu terima $\mathrm{H}_{1}$ ( $p$-value $\left.<0,05\right)$ dengan hipotesis:

1. $\mathrm{H}_{0}$ : metode common effect

2. $\mathrm{H}_{1}$ : metode fixed effect

Berdasarkan hasil dari pengujian Chow Test diatas, maka metode yang dipilih yaitu metode Fixed Effect. Namun hal tersebut belum merupakan hasil akhir atas pemilihan model terbaik. Maka perlu dilihat hasil dari pengujian hausman test untuk memilih model manakah yang lebih baik Random Effect atau Fixed Effect. Berikut merupakan hasil output dari uji menggunakan hausman test:

Tabel 3 Hasil Uji Model Menggunakan Hausman Test

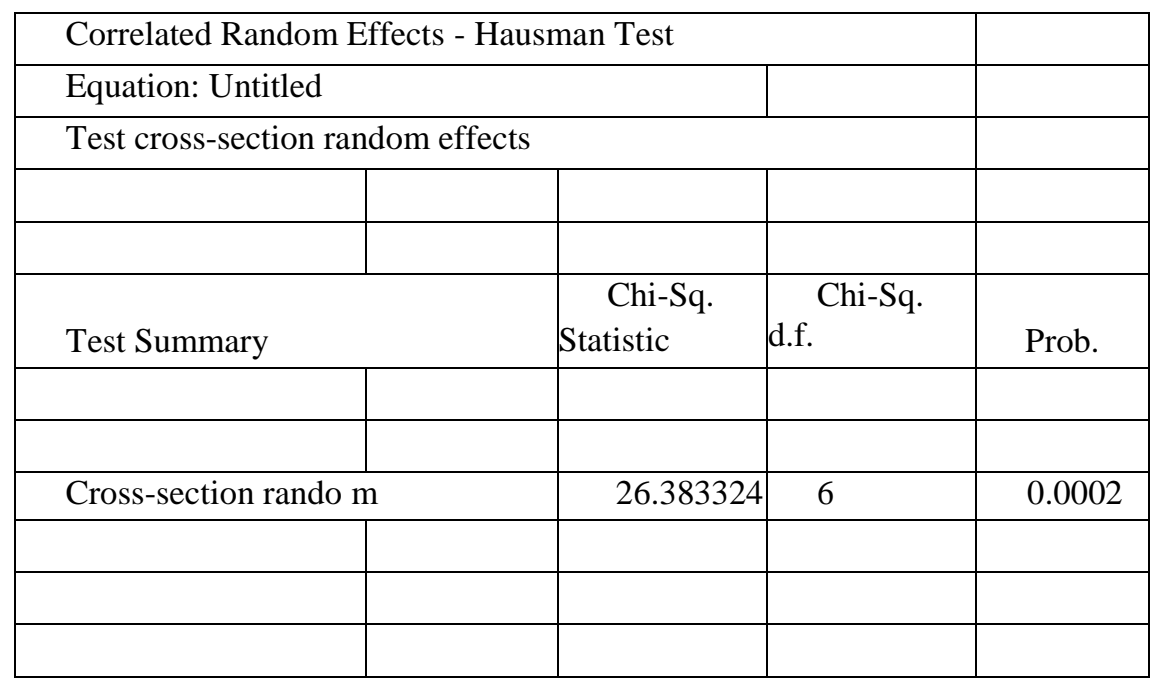


Pada hasil pengujian yang telah dilakukan diatas, dapat dilihat bahwa nilai probabilitas pada test cross-section random memperlihatkan angka bernilai $0,0002<0,05$. Sehingga keputusan yang diambil pada pengujian Hausman Test ini yaitu terima $\mathrm{H}_{1}(p$-value $<0,05)$ dengan hipotesis:

1. $\mathrm{H}_{0}$ : metode random effect

2. $\mathrm{H}_{1}$ : metode fixed effect

Berdasarkan hasil pengujian Hausman Test, maka metode pilihan yang dianggap paling baik digunakan dalam penelitian ini adalah metode Fixed Effect.

\section{Analisis Regresi Data Panel}

Penelitian ini menggunakan variabel Debt Rasio, Long term debt to Equity Ratio, Time Interest Earned Ratio, ROA, NPM dan ROE sebagai variabel independen dan Nilai Perusahaan sebagai variabel dependen.

Hipotesis pertama menyatakan bahwa variabel independen mempunyai pengaruh secara serempak terhadap variabel dependen pada perusahaan Properti dan Real Estatedi Bursa Efek Indonesia. Hipotesis kedua sampai ketiga menyatakan variabel independen mempunyai pengaruh secara parsial terhadap variabel dependen.

Untuk membuktikan hipotesis yang dikemukakan dalam penelitian ini menggunakan alat analisis regresi data panel mengukur pengaruh Debt Rasio, Long term debt to Equity Ratio, Time Interest Earned Ratio, ROA, NPM dan ROE sebagai variabel independen dan Nilai Perusahaan pada perusahaan Industri Makanan dan Minuman di Bursa Efek Indonesia..

Hasil perhitungan regresi data panel dari penelitian ini dapat dilihat pada Tabel 4 berikut ini:

Tabel 4 Hasil Regresi Data Panel

\begin{tabular}{|c|c|c|c|c|}
\hline $\begin{array}{l}\text { Variabel } \\
\text { Dependen }\end{array}$ & Variabel Independen $(\mathrm{X})$ & Koefisien & t hitung & Sig. \\
\hline & Debt Ratio (X1) & 1,543096 & 2,445091 & $\begin{array}{c}0.0192< \\
0,05\end{array}$ \\
\hline \multirow{5}{*}{$\begin{array}{c}\text { Nilai } \\
\text { Perusahaan }\end{array}$} & Time Interest Earned Ratio(X2) & -0.005312 & $-1,085694$ & $0.2845>0,05$ \\
\hline & Long term-debt to Equity Ratio(X3) & $7,00 \mathrm{E}-05$ & 1,423877 & $0.1626>0,05$ \\
\hline & ROA $(\mathrm{X} 4)$ & 3,994066 & 1,957822 & $0.0576>0,05$ \\
\hline & NPM (X5) & $-4,781824$ & $-1,124615$ & $0.2678>0,05$ \\
\hline & ROE (X6) & 0,176667 & 0,479470 & $0.6344>0,05$ \\
\hline & Constanta & 1,009458 & F Hitung & 3.210962 \\
\hline & R-Squared & 0.845537 & Probability & 0,000011 \\
\hline \multirow{2}{*}{\multicolumn{2}{|c|}{ Adjusted R-Squared }} & 0.780500 & & \\
\hline & & & t.tabel & 2,77645 \\
\hline
\end{tabular}

Berdasarkan hasil perhitungan pada tabel 4 dapat dirumuskan persamaanregresi data panel dari penelitian ini sebagai berikut:

$$
\begin{gathered}
\mathrm{Y}=1,009458-1,543096(\mathrm{DR})+0,005312(\mathrm{TIE})+7,00(\mathrm{LTD})+3,994066(\mathrm{ROA})-4,781824(\mathrm{NPM}) \\
+0,176667(\mathrm{ROE})+\mathrm{e}
\end{gathered}
$$

Hasil persamaan regresi data panel di atas dapat dijelaskan sebagai berikut :

1. Nilai konstanta sebesar 1,009458 berarti apabila variabel independen dalam penelitian ini diabaikan atau sama dengan nol maka nilai dari nilai perusahaan industri makanan dan minuman sebesar 1,009458 satuan. 
2. Nilai koefisien regresi variabel $X_{1}$ Debt Ratio bernilai positif yaitu sebesar 1,543096 yang berarti apabila nilai variabel yang lainnya diasumsikan tetap, maka setiap peningkatan Debt Ratio sebesar 1 akan mengakibatkan meningkatnya nilai perusahaan sebesar 1,543096 satuan.

3. Nilai koefisien regresi variabel $\mathrm{X}_{2}$ Times Interest Earned Ratio bernilai positif yaitu 0,005312 yang berarti apabila nilai variabel independen yang lainnya diasumsikan tetap, maka setiap peningkatan Times Interest Earned Ratiosebesar 1 akan meningkatkan nilai perusahaan sebesar 0,005312 satuan.

4. Nilai koefisien regresi variabel $\mathrm{X}_{3}$ Long term-debt to Equity Ratio bernilai positif yaitu 7,00 yang berarti apabila nilai variabel independen yang lainnya diasumsikan tetap, maka setiap peningkatan Long term-debt to Equity Ratio sebesar 1 akan meningkatkan nilai perusahaan sebesar 7,00 satuan.

5. Nilai koefisien regresi variabel $\mathrm{X}_{4}$ ROA bernilai positif yaitu sebesar 3,994066 yang berarti apabila nilai variabel yang lainnya diasumsikan tetap, maka setiap peningkatan ROA sebesar 1 maka akan mengakibatkan peningkatan terhadap nilai perusahaan sebesar 3,994066 satuan.

6. Nilai koefisien regresi variabel $X_{5}$ NPM bernilai negatif yaitu sebesar $-4,781824$ yang berarti apabila nilai variabel yang lainnya diasumsikan tetap, maka setiap peningkatan NPM sebesar 1 maka akan mengakibatkan penurunan terhadap nilai perusahaan sebesar $-4,781824$ satuan.

7. Nilai koefisien regresi variabel $\mathrm{X}_{6} \mathrm{ROE}$ bernilai positif yaitu sebesar 0,176667 yang berarti apabila nilai variabel yang lainnya diasumsikan tetap, maka setiap peningkatan ROE sebesar 1 maka akan mengakibatkan peningkatan terhadap nilai perusahaan sebesar 0,176667 satuan.

\section{Pengujian Hipotesis}

\section{Uji Secara Serempak (Uji F)}

Uji F atau uji simultan untuk menguji pengaruh variabel independen secara serempak. Berikut hasil uji simultan atau uji F dapat dilihat pada Tabel 5 berikut :

Tabel 5 Hasil Uji F

\begin{tabular}{|c|c|c|c|}
\hline R-squared & 0.483863 & Mean dependent var & 1.758171 \\
\hline Adjusted R-squared & 0.419346 & S.D. dependent var & 1.793773 \\
\hline S.E. of regression & 1,947786 & Akaike info criterion & 3.751092 \\
\hline Sum squared resid & 159,9222 & Schwarz criterion & 4.371541 \\
\hline Log likelihood & - & Hannan-Quinn criter. & 3.991025 \\
\hline F-statistic & 3.210962 & Durbin-Watson stat & 3.017683 \\
\hline Prob(F-statistic) & 0.000011 & & \\
\hline
\end{tabular}

Kriteria pengujian hipotesis yang pertama dalam penelitian ini adalah dengan membandingkan Prob $\mathrm{F}_{\text {hitung }}(0,000011)<0,005$ dengan taraf maka kesimpulannya $\mathrm{H}_{0}$ diterima dan $\mathrm{H}_{1}$ ditolak. Dapat diartikan bahwa seluruh variabel independen yaitu Debt Rasio, Long term debt to Equity Ratio, Time Interest Earned Ratio, ROA, NPM dan ROE yang dimasukkan dalam model secara simultan atau serempak berpengaruh signifikan terhadap variabel dependen yaitu Nilai Perusahan. Maka dari pernyataan diatas disimpulkan bahwa dalam penelitian ini hipotesis pertama yang menyatakan bahwa Debt Rasio, Long term debt to Equity Ratio, Time Interest Earned Ratio, ROA, 
NPM dan ROE secara bersama - sama berpengaruh terhadap Nilai Perusahaan Industri makanan dan Minuman di Bursa Efek Indonesia.

\section{Uji Parsial (Uji t)}

Uji t atau uji parsial merupakan pengujian terhadap pengaruh masing-masing variabel independen yaitu Debt Rasio, Long term debt to Equity Ratio, Time Interest Earned Ratio, ROA, NPM dan ROE terhadap variabel dependen yaitu nilai perusahaan. Uji parsial pada fungsi estimasi bertujuan untuk membuat kesimpulan mengenai pengaruh masing-masing variabel independen terhadap variabel dependen. Berikut merupakan hasil uji t atau uji parsial.

Tabel 6 Hasil Uji Parsial (t Test)

\begin{tabular}{|c|c|l|c|c|}
\hline Variable & Coefficient & Std. Error & t-Statistic & Prob. \\
\hline C & 1,009458 & 0,340118 & 2,967961 & 0,0052 \\
\hline Debt & 1,543096 & 0,631100 & 2,445091 & 0,0192 \\
\hline TIE & $-0,0055312$ & 0,0044893 & $-1,085694$ & 0,2845 \\
\hline LTD & $7,00 \mathrm{E}-05$ & $4,92 \mathrm{E}-05$ & 1,423877 & 0,1626 \\
\hline ROA & 3,994066 & 2,040056 & 1,957822 & 0,0576 \\
\hline NPM & $-4,781824$ & 4,251965 & $-1,124615$ & 0,2678 \\
\hline ROE & 0,176667 & 0,368464 & 0,479470 & 0,6344 \\
\hline
\end{tabular}

Berdasarkan hasil uji-t di atas maka dapat diperoleh beberapa kesimpulan sebagai berikut:

\section{Debt Ratio $\left(\mathbf{X}_{1}\right)$}

Pengujian tentang berpengaruh atau tidaknya variabel Debt Ratio terhadap Nilai Perusahaan adalah dengan melihat taraf signifikansi $(0,0192<0,05)$ dan nilai koefisien 1,543096. Taraf signifikansi memberikan makna bahwa Debt Ratio berpengaruh secara signifikan terhadap nilai perusahaan sedangkan nilai koefisien memberikan makna bahwa pengaruh yang diberikan variabel Debt Ratio terhadap nilai perusahaan berpengaruh positif. Maka dari pernyataan diatas disimpulkan bahwa hipotesis kedua yang menyatakan variabel Debt ratio secara parsial berpengaruh signifikan terhadap nilai perusahaan Industri Makanan dan Minuman di Bursa Efek Indonesia periode 2010-2014.

\section{Time Interest Earned Ratio $\left(\mathbf{X}_{2}\right)$}

Pengujian tentang berpengaruh atau tidaknya variabel Time Interest Earned Ratioterhadap Nilai Perusahaan adalah dengan melihat taraf signifikansi $(0,2845>0,05)$ dan nilai koefisien $-0,0055312$. Taraf signifikansi memberikan makna bahwa Time Interest Earned Ratio tidak berpengaruh secara signifikan terhadap nilai perusahaan. Maka dari pernyataan diatas disimpulkan bahwa hipotesis kedua yang menyatakan variabel Time Interest Earned Ratio secara parsial tidak berpengaruh signifikanterhadap nilai perusahaan Industri Makanan dan Minuman di Bursa Efek Indonesia periode 2010-2014.

\section{Long term debt to Equity Ratio $\left(\mathrm{X}_{3}\right)$}

Pengujian tentang berpengaruh atau tidaknya variabel Long term-debt to Equity Ratio terhadap Nilai Perusahaan adalah dengan melihat taraf signifikansi $(0,1626>0,05)$ dan nilai koefisien 7,00. Taraf signifikansi memberikan makna bahwa Long term-debt to Equity Ratiotidak berpengaruh secara signifikan terhadap nilai perusahaan. Maka dari pernyataan diatas disimpulkan bahwa hipotesis kedua yang menyatakan variabel Long term-debt to Equity Ratio secara parsial tidak berpengaruh signifikan terhadap nilai perusahaan Industri Makanan dan Minuman di Bursa Efek Indonesia periode 20102014. 


\section{ROA $\left(\mathbf{X}_{4}\right)$}

Pengujian tentang berpengaruh atau tidaknya variabel ROA terhadap Nilai Perusahaan adalah dengan melihat taraf signifikansi $(0,0576>0,05)$ dan nilai koefisien 3,994066. Taraf signifikansi memberikan makna bahwa ROAtidak berpengaruh secara signifikan terhadap nilai perusahaan. Maka dari pernyataan diatas disimpulkan bahwa hipotesis kedua yang menyatakan variabel ROA secara parsial tidak berpengaruh signifikan terhadap nilai perusahaan Industri Makanan dan Minuman di Bursa Efek Indonesia periode 2010-2014.

\section{$\operatorname{NPM}\left(X_{5}\right)$}

Pengujian tentang berpengaruh atau tidaknya variabel NPMterhadap Nilai Perusahaan adalah dengan melihat taraf signifikansi $(0,2678>0,05)$ dan nilai koefisien $-4,781824$. Taraf signifikansi memberikan makna bahwa NPM tidak berpengaruh secara signifikan terhadap nilai perusahaan. Maka dari pernyataan diatas disimpulkan bahwa hipotesis kedua yang menyatakan variabel NPM secara parsial tidak berpengaruh signifikan terhadap nilai perusahaan Industri Makanan dan Minuman di Bursa Efek Indonesia periode 2010-2014.

\section{ROE $\left(\mathbf{X}_{6}\right)$}

Pengujian tentang berpengaruh atau tidaknya variabel ROEterhadap Nilai Perusahaan adalah dengan melihat taraf signifikansi $(0,6344>0,05)$ dan nilai koefisien 0,176667 . Taraf signifikansi memberikan makna bahwa ROE tidak berpengaruh secara signifikan terhadap nilai perusahaan. Maka dari pernyataan diatas disimpulkan bahwa hipotesis kedua yang menyatakan variabel ROE secara parsial tidak berpengaruh signifikan terhadap nilai perusahaan Industri Makanan dan Minuman di Bursa Efek Indonesia periode 2010-2014.

\section{Koefisien Determinasi $\left(\mathbf{R}^{2}\right)$}

Persentase pengaruh semua variabel independen terhadap variabel dependen ditunjukkan oleh besarnya koefisien determinasi yang dapat dilihat dari nilai $R$ Squared. Apabila $R$ Squared mendekati 1 , maka dapat dikatakan bahwa variabel independen yang digunakan dapat menjelaskan variabel dependen secara keseluruhan, begitu pula sebaliknya. Berikut ini merupakan hasil $R$ Squared.

Tabel 7 Nilai $R$ Squared

\begin{tabular}{|c|c|c|c|}
\hline R-squared & 0.483863 & Mean dependent var & 1.758171 \\
\hline Adjusted R-squared & 0.419346 & S.D. dependent var & 1.793773 \\
\hline S.E. of regression & 1,947786 & Akaike info criterion & 3.751092 \\
\hline Sum squared resid & 159,9222 & Schwarz criterion & 4.371541 \\
\hline Log likelihood & -86.15504 & Hannan-Quinn criter. & 3.991025 \\
\hline F-statistic & 3.210962 & Durbin-Watson stat & 3.017683 \\
\hline Prob(F-statistic) & 0.000011 & & \\
\hline
\end{tabular}

Hasil perhitungan yang diperoleh besarnya koefisien determinasi yang disesuaikan $(R$ Squared) adalah 0.483863 . Artinya semua variabel independen terhadap perubahan nilai variabel dependen adalah $48,38 \%$ dan sisannya $51,62 \%$ dipengaruhi oleh variabel lain selain variabel independen yang digunakan dalam regresi data panel.

\section{Pembahasan}

Berdasarkan hasil penelitian yang menguji pengaruh antara Debt Ratio, Long term-debt to Equity Ratio, Times Interest Earned Ratio, ROA, NPM dan ROE terhadap Nilai Perusahaan diatas, maka ada beberapa hal yang dapat dijelaskan dalam penelitian ini, yaitu sebagai berikut:

Hasil regresi dengan menggunakan tingkat signifikansi $\alpha=5 \%$ menunjukan hasil sebagai berikut Probability $=0,000011$. Hasil ini memberikan dasar penarikan kesimpulan bahwa hipotesis nol $\left(\mathrm{H}_{0}\right)$ 
diterima, artinya secara bersama - sama seluruh variabel independen (Debt Ratio, Long term-debt to Equity Ratio, Times Interest Earned Ratio, ROA, NPM dan ROE) berpengaruh signifikan terhadap nilai perusahaan.

\section{Pengaruh Debt Ratio terhadap Nilai Perusahaan}

Pada penelitian ini diperoleh hasil bahwa Debt Ratio $\left(\mathrm{X}_{1}\right)$ mempunyai pengaruh signifikan terhadap nilai perusahaan dengan nilai probabilitas 0,0192 lebih kecil dari 0,05 dengan tingkat $\alpha=5 \%$. Hal ini sesuai dengan yang diprediksikan Debt Ratio mempunyai pengaruh yang positif terhadap nilai perusahaan, apabila dikaitkan dengan hasil perhitungan memperlihatkan bahwa selama kurun waktu lima tahun penggunaan hutang dalam industri ini masih dapat dijamin oleh total aset yang dimiliki masing - masing perusahaan. Hasil penelitian ini sejalan dengan penelitian yang dilakukan oleh sukirni (2012), Sri dan wirajaya(2013) yang menyatakan bahwa rasio hutang berpengaruh signifikan terhadap nilai perusahaan.

\section{Pengaruh Times Interest Earned Ratio terhadap Nilai Perusahaan}

Times Interest Earned Ratio $\left(\mathrm{X}_{2}\right)$ tidak mempunyai pengaruh signifikan terhadap nilai perusahaan. Hasil penelitian ini tidak sesuai dengan pendapat yang dikemukakan oleh Brigham (2006) yang mengatakan bahwa apabila TIE semakin menurun maka akan menyebabkan masalah dan berujung pada kegagalan membayar bunga sehingga dapat mempengaruni nilai perusahaan. Hasil penelitian menggambarkan dengan jelas TIE tidak mempengaruhi nilai perusaahan, seperti halnya pada saat TIE menurun sebailknya nilai perusahaan meningkat. Hasil penelitian ini sejalan dengan penelitian yang dilakukan oleh sukirni (2012), frederik (2015), yang menyatakan bahwa rasio hutang tidak berpengaruh terhadap nilai perusahaan.

\section{Pengaruh Long term-debt to Equity Ratio terhadap Nilai Perusahaan}

Pada penelitian ini membuktikan bahwa variabel Long term-debt to Equity Ratio tidak mempunyai pengaruh signifikan terhadap nilai perusahaan. Hasil penelitian ini sesuai dengan pendapat yang dikemukakan oleh Dendawijaya (2005:121) yang mengatakan "Debt rasio merupakan ukuran kemampuan perusahaan dalam menutup sebagian/seluruh hutang-hutangnya, baik jangka panjang maupun jangka pendek dengan dana yang berasal dari modal perusahaan sendiri”. Bila perusahaan dapat mengatur kombinasi antara pinjaman, utang dan modal sendiri maka perusahaan dapat memaksimalkan nilai perusahaan. Hasil penelitian menunjukan rata - rata perusahaan yang masuk dalam industri makanan dan minuman nilai perusahaanya tidak dipengaruhi oleh long ter-debt to equity ratio. Hasil penelitian ini sejalan dengan penelitian yang dilakukan oleh Sukirni (2012), \& Triagustina, dkk (2012)

\section{Pengaruh ROA terhadap Nilai Perusahaan}

Pada penelitian ini membuktikan bahwa variabel ROA tidak mempunyai pengaruh signifikan terhadap nilai perusahaan. Hasil penelitian ini tidak sejalan dengan pendapat yang dikemukakan oleh Bambang Riyanto (2010) dimana profitabilitas yang tinggi merupakan suatu keberhasilan perusahaan yang dalam memperoleh laba berdasarkan aktivanya maupun berdasarkan modal sendiri. Menjaga tingkat profitabilitas merupakan hal yang penting bagi perusahaan karena profitabilitas yang tinggi merupakan tujuan setiap perusahaan. Jika dilihat dari rasio profitabilitas menunjukan suatu peningkatan hal tersebut menunjukan kinerja perusahaan yang efisien, dan pendapat Mardiyanto (2009: 196) Semakin besar ROA, semakin besar pula tingkat keuntungan yang dicapai oleh perusahaan tersebut dansemakin baik pula posisi perusahaan tersebut dari segi penggunaan asset. Peningkatan daya tarik perusahaan menjadikan perusahaan tersebut makin diminati investor, karena tingkat pengembalian akan semakin besar. Hal ini juga akan berdampak terhadap harga saham dari perusahaan tersebut di pasar modal sehingga nilai perusahaan akan semakin baik pula dengan adanya peningkatan ROA, apabila kita merujuk pada hasil penelitian ini memperlihatkan bahwa rata - rata 
industri cukup baik dalam mengelola aset yang dimiliki untuk menghasilkan laba yang ditandai dengan perkembangan ROA. Hasil penelitian ini tidak sejalan dengan penelitian yang dilakukan oleh Triagustina, dkk (2012), \& Moniaga (2013)

\section{Pengaruh NPM terhadap Nilai Perusahaan}

Pada penelitian ini membuktikan bahwa variabel NPM tidak mempunyai pengaruh signifikan terhadap nilai perusahaan. Hasil penelitian ini tidak sejalan dengan pendapat yang dikemukakan oleh Bastian dan Suhardjono (2006: 299) Net Profit Margin adalah perbandingan antara laba bersih dengan penjualan. Semakin besar NPM, maka kinerja perusahaan akan semakin produktif, sehingga akan meningkatkan kepercayaan investor untuk menanamkan modalnya pada perusahaan tersebut dan nilai perusahaan akan semakin membaik dengan pendapatan laba dari penanaman modal para investor. Selain itu, rasio NPM dapat mengukur kemampuan manajemen perusahaan dalam menjalankan kegiatan operasionalnya dengan meminimalkan beban perusahaan dan memaksimalkan laba perusahaan sehingga dapat meningkatkan nilai perusahaan. Apabila kita merujuk pada hasil penelitian menunjukan bahwa nilai NPM industri makanan dan minuman menggambarhan hasil penjualan dalam memperoleh laba, akan tetapi tidak memberikan pengaruh yang besar terhadap nilai perusahaan. Hasil penelitian ini sejalan dengan penelitian yang dilakukan oleh Triagustina, dkk (2012), \& Moniaga (2013)

\section{Pengaruh ROE terhadap Nilai Perusahaan}

Pada penelitian ini membuktikan bahwa variabel ROE tidak memiliki pengaruh signifikan terhadap nilai perusahaan. Hasil penelitian ini tidak sejalan dengan teori yang dikemukakan oleh Horne dan John (2005) yang mengatakan bahwa ROE sebagai salah satu rasio profitabilitas merupakan indikator yang sangat penting bagi para investor. Sedangkan hasil penelitian ini menunjukan bahwa pengelolaan modal dalam menghasilkan laba dalam industri ini dapat dikatakan baik, akan tetapi baik peningkatan ataupun penurunan ROE tidak secara langsung berpengaruh terhadap Nilai Perusahaan. Hasil penelitian ini sejalan dengan penelitian yang dilakukan oleh Triagustina, dkk (2012), \& Moniaga (2013).

\section{KESIMPULAN DAN SARAN}

\section{Kesimpulan}

1. Secara bersama-sama Debt ratio, times interest earned ratio, long-term debt to equity ratio, ROA, ROE dan NPM tidak berpengaruh signifikan terhadap nilai perusahaan industri makanan dan minuman yang terdaftar di BEI.

2. Secara parsial Debt Ratio berpengaruh signifikan terhadap nilai perusahaan industri makanan dan minuman yang terdaftar di BEI.

3. Secara parsial Times Interest Earned Ratio tidak berpengaruh signifikan terhadap nilai perusahaan industri makanan dan minuman yang terdaftar di BEI.

4. Secara parsial Long-Term Debt to Equity Ratio tidak berpengaruh signifikan terhadap nilai perusahaan industri makanan dan minuman yang terdaftar di BEI.

5. Secara parsial ROA tidak berpengaruh signifikan terhadap nilai perusahaan industri makanan dan minuman yang terdaftar di BEI.

6. Secara parsial NPM tidak berpengaruh signifikan terhadap nilai perusahaan industri makanan dan minuman yang terdaftar di BEI.

7. Secara parsial ROE tidak berpengaruh signifikan terhadap nilai perusahaan industri makanan dan minuman yang terdaftar di BEI.

\section{Saran}

Berdasarkan hasil penelitian yang dilakukan, maka penulis memberikan saran sebagai berikut, antara lain: 
1. Bagi investor, nampaknya perlu memperhatikan nilai perusahaan perusahaan dengan tetap mempertimbangkan dampak positif dan negatifnya. Dalam hal ini investor nampaknya perlu mencermati dari nilai perusahaan yang dimiliki perusahaan serta pemanfaatannya agar tepat dalam pemilihan investasi.

2. Bagi perusahaan, penentuan nilai perusahaan sangat penting bagi perusahaan. Olehnya, perusahaan khususnya industri makanan dan minuman dapat menjadikan hasil penelitian ini sebagai bahan pertimbangannya dalam penentuan nilai perusahaannya.

3. Bagi akademisi, penelitian ini hanya terbatas pada industri makanan dan minuman dengan periode penelitian yang relatif singkat, maka peneliti selanjutnya sebaiknya dapat mengembangkan hasil penelitian dengan menambahkan sektor industri lainnya sebagai sampel serta memperpanjang periode penelitianagar memperoleh hasil yang lebih akurat serta menambahkan variabel lain yang mungkin akan menunjukkan pengaruh lebih terhadap nilai perusahaan.

\section{REFERENSI}

Ang, R. (1997). Buku Pintar Pasar Modal Indonesia. Jakarta. Mediasoft Indonesia.

Bastian, I. \& Suhardjono. (2006). Akuntansi Perbankan. Edisi 1. Jakarta: Salemba Empat.

Brigham, E. F. \& Gapenski, L. C. (1996). "Intermadiate finance management" (5th ed.). Harbor

Drive: The Dryden Press.

Brighamand \& Houston. (2001). Fundamentals of Financial Management, Ninth Edition, Horcourt College, United States of America.

Dendawijaya, L. (2005). Manajemen Perbankan. Edisi 2, Penerbit Ghalia: Jakarta.

Ghozali, I. (2011). Aplikasi Analisis Multivariate dengan program IBM SPSS 19 (edisi kelima). Semarang: Universitas Diponegoro.

Moniaga, F. (2013). Struktur Modal, Profitabilitas, dan Struktur Biaya terhadap Nilai Perusahaan Industri Keramik, Porcelen dan Kaca periode 2007 - 2011. EMBA, 1(4), 433-442.

Riyanto, B. (2010). Dasar-dasar Pembelanjaan Perusahaan. Yogyakarta: BPFE.

Stevani. (2010). Pengaruh Kualitas Pelayanan Terhadap Loyalitas Pelanggan Di Salon Johnny Andrean Bandung. Fakultas Ekonomi Jurusan Manajemen. Universitas Kristen Maranatha Bandung.

Sukirni, Dwi. 2012. Kepemilikan Manajerial, Kepemilikan Institusional, Kebijakan Deviden dan Kebijakan Hutang Analisis terhadap Nilai Perusahaan. Jurnal Akuntansi.

Triagustina, L., Sukarmanto, E. \& Helliana. 2012. Pengaruh Return On Asset (ROA) dan Return On Equity (ROE) terhadap Nilai Perusahaan. Jurnal Akuntansi, 2460-6561. 